\title{
FUNCTIONS OF DISTANCE EDUCATION IN PROMOTING SOCIAL ENTERPRISES IN RURAL AREAS OF PAKISTAN: TEACHERS' AND STUDENTS' BELIEFS
}

\author{
Dr. Syed Zubair Haider*, Dr. Uzma Munawwar $\dagger$ \\ \& Imran Ismat:
}

\begin{abstract}
Social enterprise is an important idea to resolve many societal issues at micro and macro level. This global concept appeared to have a significant impact on the improvement of communities. Like other countries, Pakistan has also been depositing significant resources in framework of social enterprise to supplement community services. This paper therefore, examined the beliefs about the functions of distance education in promoting social enterprises in rural areas of Punjab. Total 360 students and 120 teachers (with rural background) from 06 universities were the sample of the study. The data were collected purposively using two separate questionnaires. Multilevel analyses were performed to measure the participants' beliefs. It is obvious from the findings that distance education performed significantly to enhance the awareness of social enterprises in the rural setting. This awareness also demonstrates as social services and attempt to enhance social set-up of the rural residents.
\end{abstract}

Keywords: Distance Education, Social Enterprise, Rural Area, Higher Education

Assistant Professor, Department of Educational Training, The Islamia University of Bahawalpur, Punjab. Pakistan. E-mail: zubairiub@hotmail.com

+ Assistant Professor, Department of Education, Govt. Sadiq College Women University, Bahawalpur, Punjab. Pakistan.

₹ Research Scholar \& Secondary School Educator, Department of School Education, Rahim Yar Khan, Govt. of Punjab, Pakistan. 


\section{Introduction}

Social enterprises (SE) are collective social goals and their profits may be taken in the form of community betterment instead of being driven by the need to capitalize revenue for investors and owners (DTI, 2002). Social enterprises can perform a significant contribution in community development as they offer their services to those who are in trouble, and they may provide work opportunities to those who find it difficult to compete in labour market. An example of such enterprise is non-governmental organizations who do not directly work under the control of the government. However, they may get financing from the state, and may add to the benefits of the community (Clarke, Eustace, \& Wexford, 2009). All over the world, social enterprises and the individuals behind them are handling social problems (Bacq \& Janssen, 2011).

This is different from traditional business and conventional non-profit activities (Young, 2008). They are private organizations, work for the interest of general public and composed with an entrepreneurial strategy. Their ultimate intention is not to increase the revenue rather than the achievement of certain social objectives (Harding, 2010). Stroud (2008) defines the social enterprise as an association started by a group of individuals with intent to advantage the community, in which the material interest of the financial specialists is liable to confine. This is completely different from other organizations and helpful for groups while considering that through the social enterprises, individuals can get the training and the business attitude (Defourny \& Nyssens, 2010). They also helped to resolve social issues through a business approach. This approach serves to guarantee the monetary maintainability of such enterprises (Yunus, 2007). Galera and Borzaga (2009) described that they are non-profit organizations who provide community service and work-integration, which strengthen the mutual concern of the society. Since the late 1990s, the idea of the social enterprise received recognition in the several nations; however, the area is developing quickly in South Asia and specifically in Pakistan.

In Pakistan, the social enterprises are recently beginning and mapping the development at an early stage. They are self-governing organizations created by the regional individuals followed by mutual aims and an aspiration to promote society (Clarke, Eustace, \& Wexford, 2009). Local individuals get confidence to start their business for the personal advancement and community development. They worked as a medium of driving that may be primarily supported by donations or foreign aid, but the ultimate purpose is to develop sustainable income tributaries from which new generation take benefit. In a theoretical sense, social enterprise changes the nation's focus from foreign aids to its intrinsic impending and potential. Presently, in Pakistan, the rural communities seem to confront numerous social issues due to the absence of work opportunities, transport, and 
wellbeing offices. Rural social enterprises needed to grow the local community for turning it into an association. The business person needs to be aware of the business attitudes and may offer the investment support for the rural communities (Scarborough \& Cornwall, 2011). Haider and Dilshad (2015) expressed that the consistent increase in the requirement of higher education has turned into the greatest test for educational planners. This popularity has cleared a path for the distance education over the globe.

Distance education (DE)is an instructional technology for the advanced education in the $21^{\text {st }}$ century (Chowdhury \& Khatun, 2013). This is ateaching-learning process in which learners live in confined zones, where they may not be provided the best possible type of classrooms. This is an instructional process where the teacher and taught are isolated by time as well as physical separation. Students normally use different materials such as research journals, books, references, CDs/DVDs and electronic media to replace direct vis-à-vis learning. This innovative development has given new life to the distance education. In distance education, different innovative technologies like satellite, TV, phone, radio, mail, and PC are used to transfer educational guidelines. Distance education has completed four to five eras of innovation in its history (Taylor, 2001).

In Pakistan, distance education is viewed as a less prestigious education than formal education because of its low worth and absence of the facilities (Siddiqui, 2004). The initial scheme of distance education was presented in a form of Allama Iqbal Open University (AIOU). The AIOU concentrates on essential and utilitarian type of education in rural regions and has started the projects in the field of livestock and agriculture farming for enhancing the budgetary state of Pakistani individuals (Goel \& Goel, 2000). Due to an agricultural economy, $70 \%$ of the Pakistani populace lives in rural areas, while the vast majority of ladies of country ranges are uneducated due to the work responsibilities and family issues. The AIOU tries to provide educational programmes for rural ladies and play a substantial part for the betterment of rural community. It has started many educational programmes and courses to provide entrepreneurial education to rural individuals considering that most of the rural ladies cannot get education inthe regular classes.

The main objective of the present research was to study distance education functions in promoting social enterprises in rural areas. During literature review, it was noticed that research in this area involves just a minimal status both as far as quality and quantity. But in Pakistan, almost very few studies have conducted to analyze this important issue. This article, accordingly, endeavors to bridge a portion of the gap in this area.

\section{Research Methodology}

The present research examinedthe functions of distance education in promoting social enterprises in the rural areas of Pakistan. Considering the 
nature of problem, the descriptive research design was found suitable for present research.

\section{Sample and Sampling}

The study population consisted of all university students and teachers of Pakistan. However, total 360 M.Phil students and 120 teachers (80:15 from Islamia University of Bahawalpur, 60:15 from Bahauddin Zakariya University Multan, 80:30 from Allama Iqbal Open University Islamabad, 50:30 from Virtual University, 40:17 from Sindh University Jamshoro, and 50:13 from Gomal University Dere Ismail Khan) were selected purposively. The students and teachers with rural background (resident of rural areas, holding ownership of agricultural lands and farm houses in rural areas) were included in this study. Due to their better understanding regarding living style of people in range areas, their mentality and thinking level etc. As resident of rural areas, they may also have better understanding of rural problems. The students' mean age was $(\mathrm{M}=26.69$ years, $\mathrm{SD}=4.22)$ and teachers' mean age was $(M=43.41$ years, $\mathrm{SD}=6.78)$ respectively.

\section{Research Instrument}

In this study, two different questionnaires were developed to collect data from students and teachers. At the beginning of each questionnaire, demographic characteristics were asked. Students' questionnaire was comprised of 22 close-ended questions, while teachers' questionnaire consisted of 19 closed ended questions. However, after items reduction techniques such as exploratory and confirmatory factor analysis, 19 questions in the students' and 18 questions in the teachers' questionnaire were finally retained.

Table 1: Reliability and Explanatory Characteristics

\begin{tabular}{|l|c|c|c|c|c|c|}
\hline \multicolumn{1}{|c|}{ Variables } & $\begin{array}{c}\text { Number } \\
\text { of items }\end{array}$ & A & Min & Max & Mean & SD \\
\hline Student level & & & & & & \\
\hline 1. Economic Development & 7 & 0.86 & 1.00 & 5.00 & 3.51 & 0.35 \\
\hline 2. Community Development & 7 & 0.84 & 1.00 & 5.00 & 3.37 & 0.38 \\
\hline 3. Infrastructure Building & 5 & 0.91 & 1.00 & 5.00 & 3.62 & 0.31 \\
\hline Teacher level & & & & & & \\
\hline 1. Social Development & 6 & 0.88 & 1.00 & 5.00 & 3.21 & 0.51 \\
\hline 2. Financial Improvement & 5 & 0.90 & 1.00 & 5.00 & 3.46 & 0.46 \\
\hline 3. Problem Solving & 7 & 0.81 & 1.00 & 5.00 & 3.05 & 0.48 \\
\hline
\end{tabular}


Both questionnaires were based on five-point Likert scale (See table 1). In students' questionnaire the first factor, economic development (Items, 07) was developed for knowing the beliefs regarding economic advancement, the second factor, community development (Items, 07) extended to know the community betterment in the region and third factor, infrastructure building (Items, 05) was used to elicit information regarding physical facilities. In questionnaire for teachers' the dimensions, social development (06, items), financial improvement (05 items) and problem solving (07, items) were designed to elicit the teachers' beliefs.

\section{Instrument Validation \& Measurement}

A panel of four Assistant Professors evaluated the content validity of the questionnaires. The questions approved by more than $80 \%$ of the specialists were retained,whereas, improper questions were modified according to the specialists' feedback. The questionnaire was pilot tested on 12 students and 08 teachers and it was restructured to make it more reliable and valid. The researchers personally collected the required data from students and teachers. The collected data were analyzed using SPSS version $20^{\text {th }}$ and EFA, correlation and chi-square were calculated.

\section{Data Analysis}

In the current study, data analysis took place in two steps. Initially, a factor analysis was conducted on both questionnaires. In the second phase, descriptive and inferential statistical measures were applied to the data.

Table 2: Factor Matrix for Students' Beliefs Regarding Awareness of Social Enterprises through Distance Education

\begin{tabular}{|c|c|c|c|}
\hline Factor & Questions & $\begin{array}{c}\text { Factor } \\
\text { Loadings }\end{array}$ & $\begin{array}{l}\text { Variance } \\
\text { explained }\end{array}$ \\
\hline \multicolumn{4}{|c|}{ Distance education helps students for social enterprise } \\
\hline \multirow[t]{6}{*}{$\begin{array}{l}\text { Economic } \\
\text { Development }\end{array}$} & $\begin{array}{l}\text { 16. To provide opportunity to } \\
\text { run own business }\end{array}$ & 0.76 & $33.54 \%$ \\
\hline & $\begin{array}{l}\text { 1. To better social economy of } \\
\text { rural people }\end{array}$ & 0.71 & \\
\hline & 2. To make business plans & 0.68 & \\
\hline & $\begin{array}{l}\text { 13. To give financial support to } \\
\text { poor people }\end{array}$ & 0.66 & \\
\hline & 3. To create new job openings & 0.61 & \\
\hline & $\begin{array}{l}\text { 11. To enhance women } \\
\text { participation in developing } \\
\text { rural economy }\end{array}$ & 0.59 & \\
\hline
\end{tabular}




\begin{tabular}{|c|c|c|c|}
\hline & $\begin{array}{l}\text { 10. To provide opportunity for } \\
\text { small business. }\end{array}$ & 0.52 & \\
\hline \multirow[t]{7}{*}{$\begin{array}{l}\text { Community } \\
\text { Development }\end{array}$} & $\begin{array}{l}\text { 9. To provide free education to } \\
\text { poor people }\end{array}$ & 0.82 & $24.47 \%$ \\
\hline & $\begin{array}{l}\text { 5. To improve social setup of } \\
\text { rural people }\end{array}$ & 0.79 & \\
\hline & $\begin{array}{l}\text { 12. To work for reduction of } \\
\text { violence in rural areas }\end{array}$ & 0.65 & \\
\hline & $\begin{array}{l}\text { 18. To help to increase rural } \\
\text { literacy }\end{array}$ & 0.61 & \\
\hline & $\begin{array}{l}\text { 19. To provide technical } \\
\text { education to rural people }\end{array}$ & 0.52 & \\
\hline & $\begin{array}{l}\text { 17. To work for poor rural } \\
\text { students }\end{array}$ & 0.44 & \\
\hline & $\begin{array}{l}\text { 15. To facilitate rural old } \\
\text { people }\end{array}$ & 0.43 & \\
\hline \multirow[t]{5}{*}{$\begin{array}{l}\text { Infrastructure } \\
\text { Building }\end{array}$} & $\begin{array}{l}\text { 4. To work for the betterment } \\
\text { of rural roads }\end{array}$ & 0.74 & $13.19 \%$ \\
\hline & $\begin{array}{l}\text { 7. To help to improve } \\
\text { sanitation system }\end{array}$ & 0.71 & \\
\hline & $\begin{array}{l}\text { 8. To provide wood work } \\
\text { opportunity }\end{array}$ & 0.62 & \\
\hline & $\begin{array}{l}\text { 6. To provide clean water in } \\
\text { rural areas }\end{array}$ & 0.43 & \\
\hline & $\begin{array}{l}\text { 14. To improve agricultural } \\
\text { field }\end{array}$ & 0.40 & \\
\hline \multicolumn{2}{|c|}{ Total Variance Explained } & & $71.20 \%$ \\
\hline
\end{tabular}

We use EFA for exploring factor structure in the research instruments (See table 2). A PCM followed by varimax rotation was conducted to extract the un-correlated items. The results demonstrate that three-factor solution extracted in the students' data with each of their eigen values greater than 1.0 and accounted for $71.20 \%$ of the common variance. Totally 19 items were finally retained to measure three dimensions. Seven items $(1,2,3,10$, 11,13 and 16), seven items $(5,9,12,15,17,18$ and 19) and five items $(4,6$, 7,8 and 14) were loaded respectively on economic development, community development and infrastructure building. Furthermore, on the basis of CFA, three items 20, 21 and 22 were removed from questionnaire to improve goodness of fit, because these items have high association among their error variances. The CFA results for other remaining items showed a good model fit (Chi-square goodness of fit $=9.71, \mathrm{df}=18, \mathrm{p}=0.03$; $\mathrm{CFI}=0.93 ; \mathrm{TLC}=0.90$; $\mathrm{RMSEA}=0.03$; NFI=0.90) and the reliability of overall scale was 0.91 . 
Table 3: Factor matrix for Teachers' Beliefs regarding awareness of Social Enterprises through Distance Education

\begin{tabular}{|c|c|c|c|}
\hline Factor & Questions & $\begin{array}{c}\text { Factor } \\
\text { Loadings }\end{array}$ & $\begin{array}{l}\text { Variance } \\
\text { explained }\end{array}$ \\
\hline \multicolumn{4}{|c|}{ Distance education promotes learners for social enterprise } \\
\hline \multirow[t]{6}{*}{$\begin{array}{l}\text { Social } \\
\text { Development }\end{array}$} & $\begin{array}{l}\text { 6. To becomes source of } \\
\text { income for rural people }\end{array}$ & 0.74 & $29.55 \%$ \\
\hline & $\begin{array}{l}\text { 9. Work to improve rural } \\
\text { community }\end{array}$ & 0.62 & \\
\hline & $\begin{array}{l}\text { 3. To improve social setup in } \\
\text { rural area }\end{array}$ & 0.61 & \\
\hline & $\begin{array}{l}\text { 13. To become source to } \\
\text { reduce violence in rural areas }\end{array}$ & 0.53 & \\
\hline & $\begin{array}{l}\text { 8. To work for benefit of } \\
\text { handicap children }\end{array}$ & 0.51 & \\
\hline & $\begin{array}{l}\text { 1. To develop attitude towards } \\
\text { work }\end{array}$ & 0.46 & \\
\hline \multirow[t]{5}{*}{$\begin{array}{l}\text { Financial } \\
\text { Improvement }\end{array}$} & $\begin{array}{l}\text { 2. To improve the economy of } \\
\text { rural women }\end{array}$ & 0.72 & \\
\hline & $\begin{array}{l}\text { 15. To become a source of } \\
\text { income for poor rural people }\end{array}$ & 0.64 & $21.45 \%$ \\
\hline & $\begin{array}{l}\text { 18. To provide an opportunity } \\
\text { to run their own business }\end{array}$ & 0.63 & \\
\hline & $\begin{array}{l}\text { 5. To give financial support to } \\
\text { the rural shopkeepers }\end{array}$ & 0.62 & \\
\hline & $\begin{array}{l}\text { 7. To give financial support to } \\
\text { poor students }\end{array}$ & 0.56 & \\
\hline \multirow[t]{7}{*}{$\begin{array}{l}\text { Problem } \\
\text { Solving }\end{array}$} & $\begin{array}{l}\text { 14. To improve an agricultural } \\
\text { field. }\end{array}$ & 0.81 & \\
\hline & $\begin{array}{l}\text { 12. To arrange the clean water } \\
\text { in rural areas }\end{array}$ & 0.74 & \\
\hline & $\begin{array}{l}10 . \text { To works for solutions of } \\
\text { rural problems }\end{array}$ & 0.72 & \\
\hline & $\begin{array}{l}\text { 17. To work to provide technical } \\
\text { education to rural women }\end{array}$ & 0.62 & $15.88 \%$ \\
\hline & $\begin{array}{l}\text { 4. To work for pavement of } \\
\text { infrastructure in rural areas }\end{array}$ & 0.52 & \\
\hline & $\begin{array}{l}\text { 16. To increase knowledge of } \\
\text { rural old people }\end{array}$ & 0.51 & \\
\hline & $\begin{array}{l}\text { 11. To provide opportunity of } \\
\text { free education to rural people }\end{array}$ & 0.43 & \\
\hline \multicolumn{2}{|c|}{ Total Variance Explained } & & $66.88 \%$ \\
\hline
\end{tabular}


For teachers' questionnaire, EFA with a PCM followed by varimax rotation was conducted to extract the un-correlated items of questionnaire (See table 3). The results demonstrate three-factor solution in teachers' data with each of their eigenvalues greater than 1.0 and accounted for $66.88 \%$ of common variance. Only 18 questions of high loadings were retained in teachers' questionnaire. The three factors were related to social development 6 items $(1,3,6,8,9$ and 13), financial improvement 5 items $(2,5,7,15$ and 18) and problem solving 7 items (4, 10, 11, 12, 14, 16 and 17). Additionally, CFA for the research tool demonstrates a high association among the error variances of question 19. This single item was removed to improve the goodness of fit. The CFA results for other remaining items revealed that CFA model fitted data very well (Chi-square goodness of fit $=8.69, \mathrm{df}=17$, $\mathrm{p}=0.01 ; \mathrm{CFI}=0.93 ; \mathrm{TLC}=0.91 ; \mathrm{RMSEA}=0.04 ; \mathrm{NFI}=0.92)$ and the reliability of overall scale was 0.89 .

\section{Table 4: Correlation Matrix Between Students' and Teachers'} Dimensions

\begin{tabular}{|l|c|c|c|c|c|c|}
\hline & 1 & 2 & 3 & 4 & 5 & 6 \\
\hline Student-level & & & & & & \\
\hline 1. Economic Development & - & & & & & \\
\hline $\begin{array}{l}\text { 2. Community } \\
\text { Development }\end{array}$ & $.547^{* *}$ & - & & & & \\
\hline 3. Infrastructure Building & $.670^{* * *}$ & $.540^{* * *}$ & - & & & \\
\hline Teacher-level & & & & & & \\
\hline 4. Social Development & $.319^{* *}$ & $.338^{* *}$ & $.441^{* *}$ & - & & \\
\hline 5. Financial Improvement & .092 & $.492^{*}$ & $.337^{*}$ & $.766^{* *}$ & - & \\
\hline 6. Problem Solving & $.361^{*}$ & $.681^{*}$ & .084 & $.531^{* *}$ & $.740^{* *}$ & - \\
\hline$* *$ p $0.01, * p<0.05$ & & & & &
\end{tabular}

$* * \mathrm{p}<0.01, * \mathrm{p}<0.05$

Correlation matrix reveals statistically significant and moderate significant correlation between students' and teachers' factors (See table 4). Economic development significantly correlates with community development $(r=0.547, p<.01)$, infrastructure building $(r=0.670, p<0.01)$, social development $(r=0.319, p<0.01)$ and problem solving $(r=0.361$, $p<0.05)$. Community development is significantly associated with infrastructure building $(r=0.540, p<0.01)$, social development $(r=0.338$, $p<0.01)$, financial improvement $(r=0.492, p<0.05)$ and problem solving $(r=0.681, p<0.05)$. The infrastructure building shows significant association with social development $(r=0.441, p<0.01)$ and financial improvement $(r=0.337, p<0.05)$. Social development significantly correlates with financial improvement $(r=0.766, p<0.01)$ and problem solving $(r=0.531, p<0.01)$. 
Financial improvement shows significant correlation with $(r=0.740, p<0.01)$ respectively.

\section{Students' Beliefs}

The students' beliefs regarding economic development, community development and infrastructure building are provided below.

Table 5: Students' Beliefs on Economic Development

\begin{tabular}{|c|c|c|c|c|c|c|c|}
\hline \multirow{2}{*}{ Questions } & \multicolumn{5}{|c|}{ Level of Agreement (\%) } & \multirow{2}{*}{$\mathbf{M}$} & \multirow{2}{*}{$\begin{array}{c}\text { Chi } \\
\text { Square }\end{array}$} \\
\hline & SA & $\mathbf{A}$ & UD & DA & SDA & & \\
\hline \multicolumn{8}{|l|}{$\begin{array}{l}\text { Distance education } \\
\text { helps students for } \\
\text { social enterprise... }\end{array}$} \\
\hline $\begin{array}{l}\text { 1. To better social } \\
\text { economy of rural } \\
\text { people }\end{array}$ & 18.9 & 34.7 & 23.6 & 11.1 & 11.7 & 3.38 & 68.30 \\
\hline $\begin{array}{l}\text { 2. To make business } \\
\text { plans }\end{array}$ & 15.6 & 25.8 & 22.8 & 19.7 & 16.1 & 3.05 & 13.80 \\
\hline $\begin{array}{l}\text { 3. To create new job } \\
\text { openings }\end{array}$ & 8.3 & 22.5 & 27.8 & 25.8 & 16.6 & 2.82 & 46.10 \\
\hline $\begin{array}{l}10 . \text { To provide } \\
\text { opportunity for small } \\
\text { business. }\end{array}$ & 18.1 & 31.4 & 26.9 & 17.5 & 6.1 & 3.38 & 68.50 \\
\hline $\begin{array}{l}\text { 11. To enhance women } \\
\text { participation in } \\
\text { developing rural } \\
\text { economy }\end{array}$ & 14.4 & 32.2 & 29.4 & 17.2 & 6.7 & 3.31 & 81.80 \\
\hline $\begin{array}{l}\text { 13. To give financial } \\
\text { support to poor people }\end{array}$ & 6.9 & 24.7 & 41.7 & 24.2 & 2.5 & 3.09 & 177.40 \\
\hline $\begin{array}{l}16 \text {. To provide } \\
\text { opportunity to run own } \\
\text { business }\end{array}$ & 11.7 & 32.5 & 32.2 & 18.1 & 5.6 & 3.44 & 188.30 \\
\hline
\end{tabular}

The results revealed a significant difference between expected frequencies and observed frequencies at alpha level 0.01 (See table 5). The majority of students expressed that the social enterprise improves social economy, provide business strategies to rural individuals, provide an opportunity to run a small business, motivate rural ladies to participate in rural economic development and support poor rural individuals. However, most of students disagreed with the statement that social enterprise is creating new job. 
Table 6: Students' Beliefs on Community Development

\begin{tabular}{|l|c|c|c|c|c|c|c|}
\hline \multirow{2}{*}{ Questions } & \multicolumn{5}{|c|}{ Level of Agreement (\%) } & \multirow{2}{*}{ M } & $\begin{array}{c}\text { Chi } \\
\text { Squar } \\
\text { en }\end{array}$ \\
\cline { 2 - 6 } & SA & A & UD & DA & SDA & & \\
\hline $\begin{array}{l}\text { Distance education } \\
\text { helps students for } \\
\text { social enterprise... }\end{array}$ & & & & & & & \\
\hline $\begin{array}{l}\text { 5. To improve social } \\
\text { setup of rural people }\end{array}$ & 19.2 & 40.3 & 19.4 & 15.3 & 5.8 & 3.52 & 114.33 \\
\hline $\begin{array}{l}\text { 9. To provide free } \\
\text { education to poor } \\
\text { people }\end{array}$ & 16.7 & 33.1 & 29.2 & 17.2 & 3.9 & 3.41 & 95.91 \\
\hline $\begin{array}{l}\text { 12. To work for } \\
\text { reduction of violence } \\
\text { in rural areas }\end{array}$ & 13.6 & 37.2 & 27.5 & 16.7 & 5 & 3.38 & 113.36 \\
\hline $\begin{array}{l}\text { 15. To facilitate rural } \\
\text { old people }\end{array}$ & 6.7 & 28.1 & 36.1 & 23.1 & 5.8 & 3.18 & 223.46 \\
\hline $\begin{array}{l}\text { 17. To work for poor } \\
\text { rural students }\end{array}$ & 14.7 & 41.9 & 28.9 & 12.5 & 1.9 & 3.55 & 174.72 \\
\hline $\begin{array}{l}\text { 18. Help to increase } \\
\text { rural literacy }\end{array}$ & 20.6 & 48.1 & 21.4 & 7.5 & 2.5 & 3.77 & 225.33 \\
\hline $\begin{array}{l}\text { 19. To provide } \\
\text { technical education to } \\
\text { rural people }\end{array}$ & 10.3 & 35.6 & 41.7 & 11.9 & 0.6 & 3.43 & 224.80 \\
\hline
\end{tabular}

The results showed a significant difference between expected frequencies and observed frequencies at alpha level 0.01 (See table 6). Majority of the students believed that through distance education, social enterprises improved the setup of rural individuals, provide free education to poor rural individuals, reduce violence in remote areas, facilitate older rural individuals in community development, work for poor rural students, help to increase the rural literacy rate and provide technical education to poor rural individuals. 
Table 7: Students' Beliefs on Infrastructure Building

\begin{tabular}{|c|c|c|c|c|c|c|c|}
\hline \multirow{2}{*}{ Questions } & \multicolumn{5}{|c|}{ Level of Agreement (\%) } & \multirow{2}{*}{$\mathbf{M}$} & \multirow{2}{*}{$\begin{array}{c}\text { Chi } \\
\text { Square }\end{array}$} \\
\hline & SA & $\mathbf{A}$ & UD & DA & SDA & & \\
\hline \multicolumn{8}{|l|}{$\begin{array}{l}\text { Distance education } \\
\text { helps students for } \\
\text { social enterprise... }\end{array}$} \\
\hline $\begin{array}{l}\text { 4. To work for the } \\
\text { betterment of rural } \\
\text { roads }\end{array}$ & 5.8 & 27.8 & 33.9 & 22.2 & 10.3 & 2.97 & 99.63 \\
\hline $\begin{array}{l}\text { 6. To provide clean } \\
\text { water in rural areas }\end{array}$ & 16.4 & 33.9 & 24.2 & 20.3 & 5.3 & 3.36 & 79.22 \\
\hline $\begin{array}{l}\text { 7. Help to improve } \\
\text { sanitation system }\end{array}$ & 10.6 & 25.8 & 35 & 18.9 & 9.7 & 3.09 & 81.91 \\
\hline $\begin{array}{l}\text { 8. To provide wood } \\
\text { work opportunity }\end{array}$ & 4.2 & 19.7 & 34.2 & 28.1 & 13.9 & 2.72 & 99.66 \\
\hline $\begin{array}{l}\text { 14. To improve } \\
\text { agricultural field }\end{array}$ & 6.7 & 30.6 & 37.5 & 21.4 & 3.9 & 3.15 & 154.25 \\
\hline
\end{tabular}

The results manifested a significant difference between expected frequencies and observed frequencies at alpha level 0.01 (See table 7). Majority of students believed that distance education through social enterprises help to arrange the clean water in rural areas, improve the sanitation system in rural regions and help to improve agricultural practices in rural areas.

\section{Teachers' Beliefs}

The teachers' beliefs regarding social development, financial improvement and problem solving are provided below. 
Table 8: Teachers' Beliefs on Social Development

\begin{tabular}{|l|c|c|c|c|c|c|c|}
\hline \multirow{2}{*}{ Questions } & \multicolumn{5}{|c|}{ Level of Agreement (\%) } & \multirow{2}{*}{ M } & \multirow{2}{*}{$\begin{array}{c}\text { Chi } \\
\text { Square }\end{array}$} \\
\cline { 2 - 6 } & SA & A & UD & DA & SDA & & \\
\hline $\begin{array}{l}\text { Distance education } \\
\text { helps students for } \\
\text { social enterprise... }\end{array}$ & & & & & & & \\
\hline $\begin{array}{l}\text { 1. To develop attitude } \\
\text { towards work }\end{array}$ & 16.7 & 49.2 & 29.2 & 5 & 0 & 3.78 & 51.40 \\
\hline $\begin{array}{l}\text { 3. To improve social } \\
\text { setup in rural area }\end{array}$ & 22.5 & 44.2 & 25 & 8.3 & 0 & 3.81 & 31.26 \\
\hline $\begin{array}{l}\text { 6. To becomes source } \\
\text { of income for rural } \\
\text { people }\end{array}$ & 6.7 & 28.3 & 41.7 & 20.8 & 2.5 & 3.16 & 61.41 \\
\hline $\begin{array}{l}\text { 8. To work for benefit } \\
\text { of handicap children }\end{array}$ & 17.5 & 57.5 & 20 & 5 & 0 & 3.88 & 73.80 \\
\hline $\begin{array}{l}\text { 9. Work to improve } \\
\text { rural community }\end{array}$ & 17.5 & 28.3 & 24.2 & 22.5 & 7.5 & 3.26 & 15.33 \\
\hline $\begin{array}{l}\text { 13. To become source } \\
\text { to reduce violence in } \\
\text { rural areas }\end{array}$ & 12.5 & 35 & 35 & 16.7 & 0.8 & 3.42 & 53.08 \\
\hline
\end{tabular}

The results expressed a significant difference between expected frequencies and observed frequencies at alpha level 0.01 (See table 8). A sizable number of teachers acknowledged that distance education through social enterprises develops a missionary attitude towards work, improve the social setup of rural areas, enhance the sources of income for rural individuals, improve the condition of handicap children, improve rural community and help to reduce violence in rural settings. 
Table 9: Teachers' Beliefs on Financial Improvement

\begin{tabular}{|l|c|c|c|c|c|c|c|}
\hline \multirow{2}{*}{ Questions } & \multicolumn{5}{|c|}{ Level of Agreement (\%) } & \multirow{2}{*}{ M } & \multirow{2}{*}{$\begin{array}{c}\text { Chi } \\
\text { Square }\end{array}$} \\
\cline { 2 - 6 } & SA & A & UD & DA & SDA & & \\
\hline $\begin{array}{l}\text { Distance education } \\
\text { helps students for social } \\
\text { enterprise... }\end{array}$ & & & & & & & \\
\hline $\begin{array}{l}\text { 2. To improve the } \\
\text { economy of rural } \\
\text { women }\end{array}$ & 5.8 & 30 & 45 & 19.2 & 0 & 3.23 & 39.66 \\
\hline $\begin{array}{l}\text { 5. To give financial } \\
\text { support to the rural } \\
\text { shopkeepers }\end{array}$ & 3.3 & 32.5 & 40.8 & 23.3 & 0 & 3.16 & 37.40 \\
\hline $\begin{array}{l}\text { 7. To give financial } \\
\text { support to poor students }\end{array}$ & 15 & 44.2 & 31.7 & 9.2 & 0 & 3.65 & 36.60 \\
\hline $\begin{array}{l}\text { 15. To become a source } \\
\text { of income for poor rural } \\
\text { people }\end{array}$ & 9.2 & 39.2 & 35 & 14.2 & 1.7 & 3.40 & 65.32 \\
\hline $\begin{array}{l}\text { 18. To provide an } \\
\text { opportunity to run their } \\
\text { own business }\end{array}$ & 11.7 & 40.8 & 30.8 & 15.8 & 0.8 & 3.47 & 60.33 \\
\hline
\end{tabular}

The results described a significant difference between expected frequencies and observed frequencies at alpha level 0.01 (See table 9). Majority of teachers noticed that distance education through social enterprises provides fiscal support to the poor rural students, help to become a source of money for poor rural people and provide the rural individual, opportunity to start their own business, whereas, most of the teachers are undecided regarding the improvement in the economic conditions of rural ladies. 
Functions of Distance Education in Promoting Social Enterprises

in Rural Areas of Pakistan: Teachers' and Students' Beliefs

Table 10: Teachers' Beliefs on Problem Solving

\begin{tabular}{|l|c|c|c|c|c|c|c|}
\hline \multirow{2}{*}{ Questions } & \multicolumn{5}{|c|}{ Level of Agreement (\%) } & \multirow{2}{*}{$\begin{array}{c}\text { Chi } \\
\text { Square }\end{array}$} \\
\cline { 2 - 6 } SA & A & UD & DA & SDA & & & \\
\hline $\begin{array}{l}\text { Distance education } \\
\text { helps students for } \\
\text { social enterprise... }\end{array}$ & & & & & & & \\
\hline $\begin{array}{l}\text { 4. To work for } \\
\text { pavement of } \\
\text { infrastructure in rural } \\
\text { areas }\end{array}$ & 10 & 39.2 & 36.7 & 14.2 & 0 & 3.45 & 32.6 \\
\hline $\begin{array}{l}\text { 10. To works for } \\
\text { solutions of rural } \\
\text { problems }\end{array}$ & 15 & 50.8 & 21.7 & 12.5 & 0 & 3.68 & 44.9 \\
\hline $\begin{array}{l}\text { 11. To provide free } \\
\text { education to rural } \\
\text { people }\end{array}$ & 17.5 & 51.7 & 18.3 & 10 & 2.5 & 3.72 & 85.1 \\
\hline $\begin{array}{l}\text { 12. To arrange the } \\
\text { clean water in rural } \\
\text { areas }\end{array}$ & 20 & 48.3 & 20 & 10 & 1.7 & 3.75 & 74.3 \\
\hline $\begin{array}{l}\text { 14. To improve an } \\
\text { agricultural field. }\end{array}$ & 9.2 & 31.7 & 39.2 & 17.5 & 2.5 & 3.28 & 56.0 \\
\hline $\begin{array}{l}\text { 16. To increase } \\
\text { knowledge of rural } \\
\text { old people }\end{array}$ & 20 & 45.8 & 26.7 & 7.5 & 0 & 3.78 & 36.9 \\
\hline $\begin{array}{l}\text { 17. To work to } \\
\text { provide technical } \\
\text { education to rural } \\
\text { women }\end{array}$ & 20.8 & 45.8 & 20 & 9.2 & 4.2 & 3.70 & 62.2 \\
\hline
\end{tabular}

The results expressed a significant difference between expected frequencies and observed frequencies at alpha level 0.01 (See table 10). Majority of the teachers argued that distance education through social enterprises work for the betterment of infrastructure in rural areas, help to solve rural social problems, provide an opportunity for free education, arrange clean water for rural individuals, help to improve rural practices, help to increase knowledge of older rural people and provide technical education to rural ladies.

\section{Discussion}

Since independence, Pakistan is in a serious condition, demonstrating disappointment in community development and still idle in making 
significant advancement. The nation's shaky economy impacts especially when we take a look at social development. There are various programmes which in some way or another are supporting different sorts of rural enterprises. Social enterprise has turned out to be a well-known among academic, professionals and policy makers over the world as a potential answer for strategic issues. Galera and Borzaga (2009) identified that the expansion and subsequent identification of social enterprises is a large practice that cuts across many countries. Regardless of its significant growth, the precise definition of a social enterprise shared by the educationist dedicated to learn this phenomenon does not exist so far. However, this lack of common perceptive should not be regarded as a constraint preventing its further development. Teasdale and Baldock (2013) argued that the social enterprises and different characters from open, private, and common segments are utilizing numerous approaches to alleviate poverty, decrease social avoidance, and ponder different issues of the world as they look forward to convene the world's most squeezing needs (Fisac Garcia, Acevedo Ruiz, Moreno Romero, \& Kreiner, 2013).

The findings proved that majority of students believed that the social enterprises improve the social economy, work for the betterment of infrastructure, improve their living style and provide business strategies in rural areas. Social enterprises work for the disable person, solve the rural social problems, provide opportunities for participation of students in social activities, provide opportunity for poor rural people to run small businesses, motivate rural women to participate in the development of rural economy. They provide free education to poor rural women, it is a source of income for poor people, and facilitate the participation of rural old people in the rural development. A sizable number of students believed that social enterprises work for the poor rural students, protect old age people, increase rural literacy rate through distance education, provide an easy way to poor rural people to obtain education and provide technical education to poor rural residents.

In view of most of teachers, social enterprises emerged as a charity work. Teachers expressed their satisfaction that they provide opportunities for rural people to run their own business, improve the economy of rural women, they work to improve the social setup of rural people and give financial support to rural people. They have proved to be a source of income for poor rural people, give financial support to poor rural students, work for the benefits of handicap children and work to improve the overall rural community. The majority of teachers agree that social enterprises work for the solution of many rural problems, provide opportunity for free education to poor rural people and motivate the rural women to participate in the development of rural economy. Many teachers argued that social enterprises have become a source to reduce violence (produced due to poverty) in rural areas, it has helped to increase the knowledge of rural older people through 
distance education, and social enterprises helped many rural women to get technical education through distance education.

\section{Conclusion}

It is clear that social enterprises attempt to improve the lifestyle of rural groups for the solution of country issues, give a chance of free training to poor individuals, encourage rural ladies to play their role in the development of rural economy, it is a source to decrease viciousness in rural regions, a source of income for poor individuals, old people build their insight through distance education and rural ladies obtain specialized training through distance learning. Clearly, through distance education awareness of social enterprises, individuals better their social economy, learn business procedures, turn into the source of providing employment, serves to enhance sanitation arrangement, takes care of the rural social issues, give a chance of investment to the students, give a chance to run their own small business and attempt to diminish the brutality in country territories. Considering the results of present research, the meticulousgenerality might not be appropriate due to small sample size. Researchers vigorously suggest to conduct more studies in Pakistan in same area for better understanding of problem and right decision making before drafting different policies and their implementation.

\section{References}

Bacq, S., \& Janssen, F. (2011). The multiple faces of social entrepreneurship: A review of definitional issues based on geographical and thematic criteria. Entrepreneurship \& Regional Development, 23(5), 373-403.

Chowdhury, M.M.H. \& Khatun, A. (2013). Modeling E-Learning Assisted Distance Education System for Bangladesh. International Journal of Advanced Science and Technology, 56, 131-142.

Clarke, A., Eustace, A. \& Wexford, C. (2009). Exploring Social Enterprise in nine areas in Ireland. Dublin Employment Pact, Clann Credo, Ulster Investment Trust and PLANET: Enniscorthy.

Defourny, J. \& Nyssens, M. (2010). Conceptions of social enterprise and social entrepreneurship in Europe and the United States: Convergences and divergences. Journal of Social Entrepreneurship, 1(1), 32-53.

Department for Trade and Industry (2002). Social Enterprise: A Strategy for Success, available at www.dti.gov.uk/socialenterprise.

Fisac-Garcia, R., Acevedo Ruiz, M., Moreno Romero, A. \& Kreiner, T. (2013). Therole of ICT in scaling up the impact of social enterprises. Journal of Management for Global Sustainability, 1(2), 83-105. 
Galera, G. \& Borzaga, C. (2009). Social enterprise: An international overview of its conceptual evolution and legal implementation. Social enterprise journal, 5(3), 210-228.

Goel, A. \& Goel, S. (2000). Distance education in the 21st century: Deep and Deep Publications.

Haider, S.Z. \& Dilshad, M. (2015). Higher Education and Global Development: A Cross Cultural Qualitative Study in Pakistan. Higher Education for the Future, 2(2), 175-193.

Harding, R. (2010). Hidden social enterprises: Why we need to look again at the numbers. London: Delta/IFF Research.

Siddiqui, M.H. (2004). Distance Learning Technologies in Education: APH Publishing.

Stroud, B. (2008). Hand book on social change. New York: Nova Science Publishers.

Taylor, J.C. (2001). Fifth generation distance education. Instructional Science and Technology, 4(1), 1-14.

Teasdale, S., Lyon, F. \& Baldock, R. (2013). Playing with numbers: A methodological critique of the social enterprise growth myth. Journal of Social Entrepreneurship, 4(2), 113-131.

Young, D. (2008). Alternative perspectives on social enterprise, in Cordes, J.J. and Steuerle, E.C. (Eds), Nonprofits Business, The Urban Institute Press, Washington, DC.

Yunus, M. (2007). Creating a world without poverty: Social business and the future of capitalism: Public Affairs

Scarborough, N.M. \& Cornwall, J.R. (2011). Essentials of entrepreneurship and small business management: Pearson London. 